\title{
Comparative Study of Learning Breaststroke Swimming Techniques Using Multi Media and Conventional Method
}

\author{
Syahrastani ${ }^{1}$ \\ ${ }^{1}$ Faculty of Sports Science, Universitas Negeri Padang, Padang, Indonesia \\ Correspondence: Syahrastani, Faculty of Sports Science, Universitas Negeri Padang, Jl. Prof. Dr. Hamka - Air \\ Tawar, Padang, Sumatera Barat, Indonesia. E-mail: syahrastani@yahoo.com
}

Received: February 12, 2014 Accepted: February 20, 2014 Online Published: February 28, 2014

doi:10.5539/ass.v10n5p152 URL: http://dx.doi.org/10.5539/ass.v10n5p152

\begin{abstract}
The purpose of this article is to find out the difference of learning breaststrokes swimming technique between students taught using multimedia and those taught using the conventional method ie images. This is an experimental research using randomized pretest-post test design. A sample of 22 equivalent ability students were chosen randomly, and divided into 2 groups; one group is taught by using multimedia and the other group using images. Key criteria in learning breaststroke swimming techniques such as: body position, hand movement, leg movement, breathing, and coordination were evaluated. Data were analysis using t-test with the significance level set at $\alpha<0.05$. Result shows that there are differences in learning breaststrokes swimming technique between the student taught by multimedia and taught by image media. The score of the group taught using structured multimedia is 416.55 , and the score of the group taught by using image media is 378.73 . The conclusion is the group of student gained higher score if taught by structured multimedia compared to being taught by image media.
\end{abstract}

Keywords: multimedia, image media, motor ability

\section{Introduction}

Education is a means to build Human Resources (HR) which is a national asset who are experts, professional, productive and self-reliant to face global competition. To improve the quality of human resources is inseparable from the role of government in education. Thus, an objective of education in Indonesia is to produce wholesome Indonesian who are physically and mentally healthy. This is in line with the aim of exercise which is to educate and establish a healthy lifestyle to produce healthy individuals. Republic of Indonesia Law No. 3 of 2005 on National Sports System Section I Article 1, paragraph 11 states that physical education and sport are implemented as part of the process of regular and ongoing education to acquire knowledge, personality, skills, health, and physical fitness. Implementation of current educational exercise is translated and adapted through school curriculum content and competency standards established by Decree No. 23 of 2006. The scope of Physical Education, Sport and Health in junior high and high schools in Indonesia covers several aspects of the subjects of physical education, sports and health, which includes aquatics.

In the aquatics syllabus, the objective is students must demonstrate the ability to do basic techniques of swimming styles which includes freestyle, breast, back and butterfly strokes. Swimming classes is currently administered intra-curricular and as extra-curricular activities. However, in reality, upon graduation from high schools, many students could not swim even though swimming is compulsory.

Students at the Faculty of Sports Science, Universitas Negeri Padang were exposed to both theoretical and practical experience in various subjects so that they become professional educators in their field after graduation. One of the compulsory subjects is swimming. Swimming is offered to the students throughout the year.

Based on a preliminary study conducted, results of the students swimming classes are not encouraging. Out of 620 students taking swimming lessons in one semester, only 62 students or $10 \%$ who got an A, 248 or $40 \%$ got a B and 186 students or $30 \%$ got grade $\mathrm{C}$, and the rest did not pass the course.

Students that did not pass the swimming course can be caused by various factors, among others, low motor ability of the students, the existing infrastructure is not adequate, as well as learning strategies that is not quite right. Of the factors mentioned above, efforts to improve learning strategy may results in improvement in student learning outcomes. Learning is a process of change in student behavior. According to Dick and Carey (2001), learning 
strategies is define as sorting and organizing aspects of the learning material and make decisions about how to present the subject matter and learning activities involved. Learning activities includes the presentation of the material, giving examples, providing training, and providing feedbacks. To optimally achieve the learning objectives, learning activities should be set by considering the characteristics of the students, the materials use, and the situation around the learning process.

Organizing learning materials and instructional media selection is part of the learning strategy. Sadiman (1990) suggested instructional media plays an important role in the learning process. Media are the various types of components in the environment that can stimulate student interest in learning, and the media are physical tools for presenting the material and stimulate students to learn in the form of books, films, tapes, and others. In a learning process are two very important elements which is the method of teaching and learning media. Both of these aspects are interrelated. The selection of one particular teaching method will affect choosing the most suitable types of media. However, it should be remember that there are many other aspects that must be considered in selecting media, such as learning objectives, type of assignment and the expected response from the students who have mastered after learning takes place, and the context of learning including student characteristics.

Appropriate learning media will help students understand the techniques of swimming movement that they need to learn. There are not many interesting learning media for swimming classes available. Instructional media in teaching swimming are usually conventional media (images or pictures).Instructional media which illustrates and explain nonverbal symbols and images, allowing students to imagine the relationship between movements in an abstract way opens the possibility for the formation of attitudes and change behavior, enhanced absorption, enhanced attention, strengthen interest, and the possibility of a complex interaction between the components in the learning process. Therefore the instructional media created should be attractive. While this application of learning media is still conventional, today's medium of learning has grown rapidly, such as instructions using multimedia. In an effort to improve student learning outcomes in swimming, a structured multimedia content for swimming classes was designed. This media was then tested to students who took the swimming courses. The purpose of this study was to determine differences in learning outcome scores in breaststroke swimming techniques between students who were taught by using structured multimedia designed with those taught using media images. The research hypothesis is that there are differences in achievement scores in breaststroke swimming techniques between the two groups.

\section{Methodology}

This is an experimental research using randomized pretest-posttest research design. The study population were male students taking basic swimming course at Universitas Pendidikan Indonesia amounting to150 students. Samples were taken at random, and 22 students with good motor skills were chosen. The students were divided into 2 groups; one group was taught using a structured multimedia approach and the second group was taught using media images. Achievement scores for breaststroke swimming technique is the total score obtained by testing the subjects in breaststroke swimming technique. Criteria to measure the learning outcome of breaststroke swimming techniques include: posture, hand movements, leg movements, breathing and coordination. Achievement test of breaststroke swimming technique aims to find the success that follows a group of students learning breaststroke swimming using multimedia instructional approach, and a group of students participating in learning by the use of media image describing breaststroke swimming technique (conventional). Data were then analyse using t-test to determine the difference in the mean scores of the two groups of students.

\section{Results and Discussion}

Based on the research that has been conducted on the two groups of students taught to learn breaststroke swimming using different learning media, the descriptive statistics and result of t-test conducted is as presented in Table1.

Table 1. Mean and standard deviation for the two groups

\begin{tabular}{llll}
\hline Group & N & Mean (SD) & t \\
\hline Students using multimedia instructions & 11 & $416.55(9.23)$ & $35.387^{*}$ \\
Students using media images (conventional) & 11 & $378.73(9.16)$ & \\
\hline$* 0<0.05$ & & &
\end{tabular}

$* \alpha<0.05$

Table 1 shows that the mean score of the learning outcomes of breaststroke swimming technique among students 
using multimedia instructions is higher than the mean score of students using media images.

Result of the t-test showed that there is a significant difference between the two groups. Analysis showed that the group using multimedia instruction learns better than the group using media images. Therefore, the hypothesis is accepted, that there is a difference in learning achievement scores of breaststroke swimming techniques among the group of students who were taught using structured multimedia design as compared to the results of learning breaststroke swimming techniques among the group of students who were taught using the media image.

The mean score of students who were taught using structured multimedia design is 416.55 , while the group of students who are taught by the media image is 378.73 . It can be concluded that the group of students who already have good psychomotor skills is able to learn swimming strokes better using structured multimedia design compared with their equivalent counterpart using the media image.

Multimedia instructional approach can be used to help students to learn the techniques of breaststroke swimming independently, according to their levels and needs. Besides, the media has been prepared in accordance with the structured learning objectives that have been set. Saguni (2006) stated multimedia provide an opportunity to learn not only from a single source such as teachers' lesson, but provides the opportunity for the subjects to develop better in terms of cognitive, creative and innovative ability. Besides, Karsa (2001) suggested the time to practice using multimedia is shorter than without multimedia which is $16 \%$ versus $37 \%$.

\section{Conclusion}

Based on the results of the research, it can be concluded that there are significant differences in learning outcomes of breaststroke swimming techniques between the group of students who were taught using structured multimedia approach with learning outcomes of breaststroke swimming techniques among the group of students who were taught using media images. It can be concluded that multimedia approach is a better option to teach swimming skills to students.

\section{References}

Dick, \& Carey. (2001). The Systematic Design of Instruction. Wesley: Educational Publishers.

Karsa, N. (n. d.). Implementation Method and Multimedia ESQ Positive impact for Students. Retrieved from http://michael001.tripod.com/mm1.htm

Maglischo, E. W. (1993). Faster Swimming Event The serious swimmer's standard reference expanded and updated. California: Mayfield Publishing Company.

Sadiman. (1990). Media Education. Jakarta: Rajawali CV.

Saguni, F. (2006, December). Cognitive Principles of Multimedia Learning: The Role of Modality and Contiguity toward Improved Learning Outcomes. Insan Research Journal, 8(3).

The laws of the Republic of Indonesia No. 3th 2005 on the National Sports System. Jakarta: Ministry of Youth and Sports of the Republic of Indonesia, 2005.

UNP Padang. (2008). Handbook for Academic Padang State University. Padang: UNP Padang.

\section{Copyrights}

Copyright for this article is retained by the author(s), with first publication rights granted to the journal.

This is an open-access article distributed under the terms and conditions of the Creative Commons Attribution license (http://creativecommons.org/licenses/by/3.0/). 